\title{
PENERAPAN MODEL PEMBELAJARAN PROBLEM BASED LEARNING UNTUK MENINGKATKAN HASIL BELAJAR SISWA SMK
}

\author{
Enok Mardiah ${ }^{1}$, Aam Hamdani ${ }^{2}$, Mumu Komaro ${ }^{3}$ \\ Departemen Pendidikan Teknik Mesin \\ Universitas Pendidikan Indonesia \\ Jl. Dr. Setiabudhi No. 207 Bandung 40154 \\ enok.mardiah@student.upi.edu
}

\begin{abstract}
ABSTRAK
Tujuan dari penelitian ini yaitu untuk mengetahui perbedaan peningkatan hasil belajar siswa antara yang menerapkan model pembelajaran Problem Based Learning dengan yang menerapkan model pembelajaran konvensional pada mata pelajaran Mekanika Teknik dan Elemen Mesin. Metode penelitian yang digunakan adalah metode eksperimen semu (quasi experiment) dengan desain penelitian yang digunakan yaitu nonequivalent control group design. Sampel yang digunakan dalam penelitian ini adalah Siswa kelas X TPM di SMK Negeri 6 Bandung dengan kelas X TPM 2 sebagai kelas kontrol dan kelas X TPM 3 sebagai kelas eksperimen. Hasil penelitian menunjukkan adanya peningkatan hasil belajar siswa yang lebih baik pada kelas yang menerapkan model pembelajaran Problem Based Learning (kelas eksperimen) dengan nilai rata-rata $N$ Gain sebesar 0,71 yang termasuk pada kategori tinggi, sedangkan kelas yang menerapkan model pembelajaran konvensional (kelas kontrol) nilai rata-rata $N$-Gain mencapai 0,49 yang termasuk pada kategori sedang.
\end{abstract}

Kata kunci: problem based learning, hasil belajar, poros, mekanika, elemen mesin.

\section{PENDAHULUAN}

Sekolah Menengah Kejuruan (SMK) merupakan sekolah lanjutan pendidikan pertama yang mempunyai tujuan utama untuk menciptakan Sumber Daya Manusia yang terampil, profesional, dan berdisiplin tinggi. Tujuan ini tercantun dalam Undang-undang Sistem Pendidikan Nasional No. 23 Tahun 2003). Salah satu usaha untuk mewujudkan tujuan tersebut adalah meningkatkan kualitas kegiatan belajar mengajar. Belajar adalah suatu proses usaha yang dilakukan individu untuk memperoleh suatu perubahan tingkah laku yang baru secara keseluruhan sebagai hasil pengalaman individu itu sendiri dalam berinteraksi dengan lingkungannya (Slameto, 2003). Faktor-faktor yang mempengaruhi hasil belajar siswa antara lain faktor dari luar (eksternal) dan faktor dari dalam (internal). Salah satu faktor eksternal yang dapat mempengaruhi belajar yaitu model pembelajaran. Model pembelajaran adalah suatu desain yang menggambarkan proses rincian dan penciptaan situasi lingkungan yang memungkinkan peserta didik berinteraksi sehingga terjadi perubahan atau perkembangan pada diri peserta didik (Sobandi, 2008). Oleh karena itu, setiap guru hendaknya menentukan model pembelajaran yang paling sesuai dengan

\footnotetext{
${ }^{1}$ Mahasiswa Departemen Pendidikan Teknik Mesin FPTK UPI

${ }^{2}$ Dosen Departemen Pendidikan Teknik Mesin FPTK UPI

${ }^{3}$ Dosen Departemen Pendidikan Teknik Mesin FPTK UPI
} 
materi yang disampaikan. Faktor model pembelajaran mempunyai peran yang besar dalam usaha mencapai tujuan pembelajaran, termasuk pembelajaran pada mata pelajaran Mekanika Teknik dan Elemen Mesin.

Mata pelajaran Mekanika Teknik dan Elemen Mesin merupakan mata pelajaran yang membahas mengenai prinsip dasar kesetimbangan struktur dan kekuatan serta komponen-komponen utama pada mesin. Mata pelajaran ini merupakan mata pelajaran wajib yang harus dipelajari oleh siswa kelas X di Sekolah Mengengah Kejuruan. Karena materi yang dipelajari pada mata pelajaran ini merupakan materi penunjang untuk materi berikutnya. Seharusnya setelah mempelajari materi-materi yang ada pada mata pelajaran ini siswa memahami penerapan materi pada kehidupan nyata. Tetapi, pada kenyataannya siswa belum mengetahui secara pasti tujuan dan implementasi dari mempelajari Mekanika Teknik dan Elemen Mesin dalam kehidupan sehari-hari.

Mata pelajaran Mekanika Teknik dan Elemen Mesin terdiri dari Sembilan Kompetensi Dasar, salah satunya yaitu menjelaskan poros, pasak dan transmisi (pulleysabuk, roda gigi dan rantai). Salah satu materi yang dibahas pada KD tersebut yaitu materi mengenai poros. Materi poros merupakan materi yang menerapkan konsep Mekanika Teknik dan Elemen Mesin, dimana siswa mempelajari mengenai tegangan, reaksi, momen, pemilihan bahan dan aplikasi poros pada bidang manufaktur. Sehingga pada saat mempelajari materi poros, siswa dituntut untuk memiliki ketekunan dan kompetensi menghitung yang mumpuni, tetapi pada kenyataannya siswa belum memiliki kemampuan tersebut sehingga berdampak pada hasil belajar yang belum optimal.

Melalui studi pendahuluan yang telah dilakukan di SMK Negeri 6 Bandung, pada proses pembelajaran Mekanika Teknik dan Elemen Mesin guru masih menerapkan model pembelajaran ceramah (konvensional) dan metode teacher centered dimana guru sebagai pengendali dan aktif menyampaikan informasi. Pembelajaran di kelas cenderung monoton sehingga pembelajaran kurang menarik. Akibat dari keadaan tersebut, akhirnya kemampuan siswa untuk memahami materi sangat rendah dan siswa tidak akan dapat memahami dan menguasai mata pelajaran yang diikutinya. Kondisi pembelajaran yang monoton siswa akan menjadi jenuh dan kurang aktif dalam mengikuti pelajaran yang diberikan. Melalui proses pembelajaran tersebut, tedapat siswa yang hasil belajaranya di bawah Kriteria Ketuntasan Minimum (KKM) yaitu sebesar 62,8\% dari 35 siswa.

Mengingat pentingnya mata pelajaran tersebut, maka diperlukan suatu upaya perbaikan agar proses pembelajaran yang diikuti siswa menjadi mudah dipahami dan siswa menjadi lebih aktif dalam proses pembelajaran. Salah satu upaya agar siswa dapat 
mengikuti proses pembelajaran secara aktif yaitu guru harus cermat dalam menggunakan suatu model pembelajaran yang inovatif dan disesuaikan dengan kondisi/ lingkungan belajar. Penggunaan model pembelajaran sangat diperlukan karena untuk mempermudah proses pembelajaran sehingga dapat mencapai hasil yang optimal. Oleh karena itu dalam proses pembelajaran Mekanika Teknik dan Elemen Mesin diperlukan suatu model pembelajaran yang dapat mempermudah proses pembelajarannya (Dimyati, 2009).

Model pembelajaran yang sering dan praktis digunakan guru dalam mengajar yaitu model pembelajaran langsung (direct instruction), model pembelajaran kooperatif (cooperative learning), model pembelajaran berbasis masalah (Problem Based Learning), model pembelajaran diskusi (discussion), model pembelajaran strategi (learning strategy) (Trianto, 2007). Model pembelajaran langsung dapat dikatakan juga sebagai model pembelajaran ekspositori. Model pembelajaran ekspositori dapat dikatakan sebagai model pembelajaran ceramah dikarenakan dalam penyampaian materi pelajaran dilakukan secara lisan/verbal (Sanjaya, 2006). Model pembelajaran berbasis masalah (Problem Based Learning) merupakan salah satu jenis ciri dari pendekatan kontekstual, yang mana konsep belajarnya adalah mengaitkan antara materi yang diajarkan dengan situasi dunia nyata dan mendorong siswa membuat hubungan antara pengetahuan yang dimilikinya. Selain itu, dengan menerapkan Problem Based Learning, masalah yang digunakan dapat membantu siswa untuk belajar berpikir kritis dan terampil dalam pemecahan masalah, sehingga mereka memperoleh pengetahuan dan konsep-konsep esensial dari materi pembelajaran (Abidin, 2009). Penerapan Problem Based Learning memberikan kebebasan kepada siswa untuk belajar sesuai dengan minat dan perhatiannya, sehingga dalam proses pembelajarannya siswa akan terlibat intensif dan aktif, yang pada akhirnya bisa membuat siswa untuk terus belajar dan dapat meningkatkan hasil belajar.

Mata pelajaran Mekanika Teknik dan Elemen Mesin perlu dikuasai dan difahami oleh seluruh siswa Teknik Pemesinan karena dalam proses pembelajarannya siswa akan belajar mengenai hal-hal yang berkaitan dengan kompetensi keahliannya. Salah satu upaya agar siswa mudah menguasai dan memahami materi yang ajarkan, guru harus melakukan proses pembelajaran dengan cara memberikan materi berdasarkan permasalahan yang konkret/nyata dan dikaitkan dengan kompetensi keahliannya. Sehingga dengan masalah nyata tersebut siswa akan merasakan bahwa mereka sedang mempelajari hal penting yang dapat berpengaruh terhadap kemampuan dan hasil belajar.

Hasil belajar berupa kapabilitas. Setelah belajar orang memiliki keterampilan, pengetahuan, sikap dan nilai (Dimyati dan Mudjiono, 2009). Hasil belajar akan berhasil 
apabila seseorang melakukan proses belajar dengan sungguh-sungguh. Selain itu, guru sebagai fasilitator harus dapat memfasilitasi siswa untuk dapat mengembangkan kemampuannya melalui proses belajar mengajar. Hasil belajar pada aspek kognitif adalah dari yang tidak tahu menjadi tahu, pada aspek psikomotor dari tidak mampu menjadi mampu dan pada aspek afektif dari yang tidak mau menjadi mau.

\section{METODE PENELITIAN}

Metode penelitian yang digunakan pada penelitian ini yaitu quasi experiment dalam bentuk Nonequivalent Control Group Design dengan pendekatan kuantitatif. Pemilihan sampel yang digunakan yaitu sampel purposive dimana pemilihan sampel ini didasarkan pada pertimbangan kemudahan dalam melakukan penelitian. Terdapat dua kelompok yang akan digunakan pada penelitian yang akan dilakukan yaitu kelompok kontrol dan kelompok eksperimen. Kelompok kontrol adalah kelompok siswa yang akan diberikan treatment dengan menerapkan model pembelajaran konvensional (ceramah), sedangkan kelompok eksperimen adalah kelompok siswa yang akan diberikan treatment dengan menerapkan model pembelajaran Problem Based Learning. Penentuan kedua kelompok ini dilihat dari hasil pre-test awal sebelum diberikan treatment. Selanjutnya setelah diberikan treatment kedua kelompok diberikan post-test untuk mengetahui peningkatan hasil belajar siswa. Instrumen yang digunakan pada pre-test dan post-test dibuat sama yaitu berupa soal uraian sebanyak lima soal.

Pengolahan data hasil penelitian yang digunakan yaitu uji homogenitas, uji normalitas, uji $\mathrm{N}$-gain dan uji hipotesis. Uji homogenitas digunakan untuk menetukan sampel dari populasi dua kelas yang homogen. Uji normalitas dilakukan untuk mengetahui apakah data yang digunakan berdistribusi normal atau tidak. Uji N-Gain dipergunakan untuk mengukur peningkatan hasil belajar siswa. Apabila kedua data bersifat homogen dan normal, maka dapat dilakukan uji hipotesis parametrik, dan apabila data tidak berdistribusi normal dan tidak homogen maka hipotesis diuji dengan pengujian statistika non parametrik.

\section{HASIL PENELITIAN}

Berdasarkan analisis dan pengolahan data, rata-rata nilai pre-test untuk kelas kontrol yaitu 1,23 dan rata-rata nilai pre-test kelas eksperimen yaitu 1,31. Berdasarkan perolehan rata-rata nilai pre-test untuk kelas kontrol dan kelas eksperimen menunjukkan adanya perbedaan antara kedua kelas yang tidak begitu signifikan, artinya kemampuan 
awal dari kedua kelas tidak jauh berbeda. Rata-rata nilai post-test untuk kelas kontrol adalah 2,59 dan rata-rata nilai post-test untuk kelas eksperimen adalah 3,21. Berdasarkan perolehan rata-rata nilai post-test untuk kelas kontrol dan kelas eksperimen menunjukkan adanya perbedaan yang signifikan. Rata-rata nilai post-test kelas eksperimen lebih baik dibandingkan dengan rata-rata nilai post-test kelas kontrol. Perbedaan hasil pre-test dan post-test diolah dengan rumus $\mathrm{N}$-gain untuk mengetahui seberapa besar perbedaan hasil belajar sebelum dan sesudah diberikan treatment. Melalui analisis dan pengolaha data didapatkan rata-rata $\mathrm{N}$-gain untuk kelas kontrol dan kelas eksperimen yaitu 0,49 dan 0,71.

Data hasil pre-test dan post-test yang dilakukan di kelas kontrol dan kelas eksperimen diolah melalui proses perhitungan dan analisis untuk menentukan langkah penelitian selanjutnya. Pengujian data dilakukan dengan melakukan analisis melalui perhitungan homogenitas, normalitas dan pengujian hipotesis. Pengujian homogenitas dilakukan dengan uji fischer (F) dengan membandingkan varians terbesar dan varians terkecil. Data yang digunakan untuk pengujian homogenitas yaitu data pre-test kedua kelas. Hasil pengujian homogenitas menghasilkan p-value sebesar 0,09. Taraf signifikasi yang ditetapkan sebelumnya yaitu $5 \%$ atau $\alpha=0,05$. Hasil perhitungan tersebut yaitu kedua kelas sampel tersebut homogen/ memiliki kesamaan. Pengujian normalitas dilakukan pada data pre-test dan post-test dari kedua kelas sampel. Pengujian ini menggunakan rumus chi-kuadrat $\left(\chi^{2}\right)$. Hasil pengujian menunjukkan bahwa semua data berdistribusi normal.

Pengujian dilakukan pada data $N$-gain dari kedua kelas sampel tersebut. Hasil pengujian hipotesis menunjukkan bahwa, nilai $t_{\text {hitung }}=7,44$. Derajat kebebasan (dk) yang digunakan yaitu $\mathrm{dk}=\left(\mathrm{n}_{1}+\mathrm{n}_{2}\right)-2=(29+22)-2=49$, sehingga didapatkan nilai $\mathrm{t}_{\text {tabel }}$ untuk dk=49 yaitu 1,67. Dengan demikian, dikarenakan $t_{\text {hitung }}=7,44>t_{\text {tabel }}=1,67$ maka kesimpulan yang dapat ditarik yaitu $\mathrm{H}_{\mathrm{o}}$ ditolak, artinya terdapat peningkatan hasil belajar dengan menerapkan model pembelajaran Problem Based Learning. Peningkatan hasil belajar siswa yang menerapkan model pembelajaran Problem Based Learning lebih baik dibandingkan dengan siswa yang menerapkan model pembelajaran konvensional.

\section{PEMBAHASAN}

Berdasarkan hasil perhitungan dan analisis data menunjukkan bahwa adanya peningkatan hasil belajar siswa di kelas yang menerapkan model pembelajaran Problem Based Learning. Nilai rata-rata N-Gain di kelas eksperimen sebesar 0,71 menunjukkan 
bahwa peningkatan hasil belajar siswa dengan menerapkan model pembelajaran Problem Based Learning berada dalam kategori baik. Adanya peningkatan hasil belajar siswa di kelas yang menerapkan model pembelajaran problem Based Learning. Penerapkan model pembelajaran Problem Based Learning siswa dapat memperoleh pengetahuan dan konsepkonsep esensial dari materi pembelajaran, karena dengan menerapkan model pembelajaran Problem Based Learning ini siswa akan lebih berpikir kritis dan terampil dalam memecahkan masalah nyata yang diberikan oleh gurunya (Abidin, 2009). Siswa lebih bersemangat dan termotivasi dalam mengikuti proses pembelajaran sehingga berpengaruh terhadap hasil belajar. Salah satu faktor ekstern yang dapat mempengaruhi hasil belajar yaitu metoda mengajar atau model mengajar. Oleh karena itu, guru harus terampil dalam memilih model pembelajaran (Slameto, 2010).

Peningkatan hasil belajar siswa yang menerapkan model pembelajaran Problem Based Learning terjadi karena pada proses pembelajaran siswa dijadikan sebagai subjek utama. Pembelajaran berbasis masalah sebagai desain kurikulum yang diidentifikasi siswa tidak sebagai penerima pasif pengetahuan tetapi sebagai pemecah masalah yang bisa mengembangkan pengetahuan". Pembelajaran dengan menerapkan model Problem Based Learning guru hanya sebagai fasilitator dan membimbing siswa agar dapat memecahkan masalah yang diberikan. Pelaksanaan pembelajaran dengan menerapkan model pembelajaran Problem Based Learning peran guru sangat berpengaruh, dikarenakan guru harus mencari masalah nyata yang sesuai dengan materi yang akan dipelajari. Adapun kekurangan dalam menerapkan model pembelajaran Problem Based Learning yaitu guru harus dapat melakukan perencanaan yang kompleks artinya guru harus pintar dalam merencanakan atau memilih masalah yang berkaitan dengan materi yang akan diberikan. Guru juga harus menjadi fasilitator yang baik agar materi yang diberikan dapat dipahami oleh seluruh siswa, serta guru harus selalu menfokuskan siswa untuk dapat memecahkan masalah yang diberikan (Munir, 2010).

Hasil perhitungan dan analisis data menunjukkan bahwa adanya peningkatan hasil belajar siswa di kelas yang menerapkan model pembelajaran Problem Based Learning. Nilai rata-rata $\mathrm{N}$-Gain di kelas eksperimen sebesar 0,49, hal ini menunjukkan bahwa peningkatan hasil belajar siswa dengan menerapkan model pembelajaran Problem Based Learning berada dalam kategori sedang. Peningkatan hasil belajar siswa dapat dipengaruhi oleh faktor intern dan faktor ektern. Faktor ekstern yang dapat mempengaruhi hasil belajar siswa salah satunya adalah dengan penerapan model pembelajaran yang diberikan guru dan kondisi kelas. Temuan yang didapatkan pada proses penelitian terkait dengan pengaruh 
antara penerapan model pembelajaran konvensional (ceramah) pada mata pelajaran Mekanika Teknik dan Elemen Mesin yaitu guru harus terampil dalam menyampaikan materi yang diberikan. Dikarenakan dengan menerapkan model pembelajaran ceramah seluruh materi itu disampaikan secara verbal (Sanjaya, 2006). Penerapan model pembelajaran ceramah menjadikan proses pembelajarannya berpusat pada guru (teacher centered). Selain itu, hal yang harus diperhatikan dalam proses penerapan model pembelajaran ceramah yaitu dalam hal menyajikan materi, guru harus tetap menjaga konsentrasi siswa dan diusahakan guru harus memberikan joke-joke yang dapat membuat kondisi pembelajaran menjadi tidak membosankan.

Hasil perhitungan dan analisis data menunjukkan bahwa peningkatan hasil belajar siswa di kelas yang menerapkan model pembelajaran Problem Based Learning lebih baik dibandingkan dengan kelas yang menerapkan model pembelajaran konvensional. Penerapan model pembelajaran Problem Based Learning merupakan suatu model pembelajaran yang mengaitkan antara materi pembelajaran dengan situasi nyata. Mendorong siswa membuat hubungan antara pengetahuan yang dimilikinya dengan penerapannya dalam kehidupan sehari-hari. Penerapan model pembelajaran Problem Based Learning mengharapkan adanya keseimbangan antara kognitif, psikomotor dan afektif. Model pembelajaran Problem Based Learning membantu siswa akan menjadi terlatih dengan kondisi nyata yang telah mereka pelajari. Materi pembelajaran yang mudah dipahami akan membuat siswa menjadi termotivasi dalam mengikuti proses pembelajaran, dengan penguasaan materi yang optimal, maka hasil belajar yang diinginkan akan tercapai (Trianto, 2007).

Penerapan model pembelajaran konvensional merupakan model pembelajaran yang berpusat pada guru, penyampaian materi secara verbal akan menjadikan kondisi pembelajaran menjadi bosan. Kelemahan dalam menerapkan model pembelajaran ceramah (konvensional) yaitu siswa akan menjadi lebih pasif dan guru akan kesulitan dalam mengetahui apakah siswa itu tertarik atau mengerti terhadap materi yang disampaikan (Djamarah, 2009). Pencapaian tujuan pembelajaran dipengaruhi oleh beberapa faktor pada proses pembelajarannya, baik itu faktor eksternal maupun faktor internal. Siswa yang merasa senang dengan proses pembelajaran yang diberikan gurunya akan secara langsung termotivasi untuk mengikuti proses pembelajaran. Hal ini menunjukkan bahwa adanya keterkaitan antara lingkungan belajar dengan motivasi siswa.

Banyak manfaat yang dapat diambil dengan menerapkan model pembelajaran Problem Based Learning diantaranya yaitu dapat membuat proses pembelajaran menjadi 
lebih menarik, menumbuhkan minat belajar dan tidak membuat bosan. Penerapkan model pembelajaran PBL siswa akan terlibat intensif dan aktif pada proses pembelajaran, sehingga bisa membuat siswa untuk terus belajar dan dapat meningkatkan hasil belajar.

\section{KESIMPULAN}

Kesimpulan penelitian ini diperoleh,sebagai berikut: peningkatan hasil belajar siswa pada mata pelajaran Mekanika Teknik dan Elemen Mesin dengan menerapkan model pembelajaran Problem Based Learning berada dalam kategori tinggi. Perbedaan peningkatan hasil belajar siswa yang menerapkan model pembelajaran Problem Based Learning lebih baik dibandingkan dengan siswa yang menerapkan model pembelajaran konvensional pada mata pelajaran Mekanika Teknik dan Elemen Mesin. Penerapan model pembelajaran Problem Based Learning dapat memberikan peningkatan hasil belajar siswa yang lebih baik dibandingkan dengan pembelajaran yang menerapkan model pembelajaran konvensional.

\section{DAFTAR PUSTAKA}

Abidin, Y. (2009). Guru dan pembelajaran bermutu. Bandung: Rizqi Press.

Dimyati, M. (2009). Belajar dan pembelajaran. Jakarta: PT. Rineka Cipta.

Djamarah, S.B \& Zain, A. (2006). Strategi belajar mengajar. Jakarta: PT. Rineka Cipta.

Munir. (2010). Kurikulum berbasis teknologi informasi dan komunikasi, cetakan kedua. Bandung: Alfabetha

Sanjaya, W. (2006). Strategi pembelajaran berorientasi standar proses pendidikan. Jakarta: Kencana Prenadamedia Group.

Slameto. (2010). Belajar dan faktor-faktor yang mempengaruhinya. Jakarta: Rineka Cipta.

Sobandi, B. (2008). Model pembelajaran kritik dan apresiasi seni rupa. Solo: Maulana Offset.

Trianto. (2007). Model-model pembelajaran inovatif berorientasi konstruktivistik. Jakarta: Prestasi Pustaka. 